\title{
Bounds Testing Approach to Cointegration: A Re-examination of FDI and Growth in Vietnam
}

\author{
PHẠM THẾ ANH \\ Nha Trang University \\ Email: theanh_dhts@yahoo.com \\ NGUYẼ̃N TH!̣ HỒNG ĐÀO \\ Nha Trang University \\ Email: hongdaontu@yahoo.com.vn
}

\section{ARTICLE INFO}

Article history:

Received:

11 March 2013

Received in revised form 08 August 2013

Accepted:

25 September 2013

Keywords:

bounds testing to

Cointegration, causality, economic growth, FDI,

Vietnam.

\begin{abstract}
This study examines the econometric and empirical evidence of both causal and long-run relationship between foreign direct investment (FDI) and economic growth in Vietnam, covering a time span of 21 years from 1991 to 2012. The recent and robust methodology of bounds testing or autoregressive distributed lag model (ARDL) approach to Cointegration is employed for the empirical analysis. This technique can capture both short-run and long-run dynamics of variables, particularly in small sample size cases. The findings indicate the existence of a Cointegration relationship between the two time series and a modest adjustment process from short-run to longrun equilibrium. Further results from Granger causality tests conducted within the error correction model confirm a bi-directional causality between economic growth and FDI over the study period.
\end{abstract}




\section{INTRODUCTION}

Over the last few decades, the relationship between foreign direct investment (FDI) and economic growth has been extensively investigated by researchers from all over the world. A large number of studies found evidence of FDI growth impacts on local economies via direct capital funding and diverse externalities or spillovers (BaliamouneLutz, 2004; Klasra, 2009). Notably, FDI can transfer modern management practices and advanced technology to local firms, and generate job opportunities for local community. Moreover, the entry of foreign rivals would force local firms to enhance efficiency and productivity. Other possible benefits were also suggested such as promoting a balancedsector economic growth, enhancing domestic firms' export capacity, improving the host country's negotiation positions, and reducing risks for firms investing in developing countries.

The growth-enhancing effect of FDI, however, remains debatable. In fact, for FDI to efficiently promote growth, a certain level of absorptive capacity is required, including human capital to absorb transferred know-how, a sufficiently developed financial market, supportive investment and trade policies, and strong institutional system (Borensztein et al., 1998; Alfaro et al., 2004). Hence, countries fail to meet those key conditions might be unlikely to realize significant benefits from FDI. Moreover, FDI could undermine growth by strongly crowding out domestic investment (Agosin \& Mayer, 2000). It could also be argued that the entry of foreign rivals, notably multinational enterprises, may force local firms to go bankrupt or to be taken over. Since the literature showed mixed evidence, the study on FDI-growth nexus for a specific economy is imperative to reach any conclusion.

While the FDI-growth nexus has been widely examined, empirical studies of Vietnam's case mainly devoted to qualitative analysis and limited quantitative evidence is found. The country has been seen as an increasingly popular destination for FDI not only in Southeast Asia but the world over when it was declared the $6^{\text {th }}$ most attractive country for FDI between 2007 and 2009 (UNCTAD, 2010). The upward trend in FDI inflows to Vietnam became noticeable since the early 1990s when a comprehensive reform known as 'Đổi mó i' (Renovation) was introduced in 1986, followed by the Foreign Investment Law enacted in December 1987. The historical reform has significantly transformed the country from a centrally-planned economy to a marketoriented economy. 
Given the modest number of empirical quantitative studies on this topic so far for Vietnam and the remarkable growth of both GDP and inward FDI in the economy, it is of analytical interest and policy significance to examine the interrelationship between these two time series. Notably, this paper employs the bounds testing or autoregressive distributed lag (ARDL) approach to Cointegration to analyze this particular linkage over the period 1991-2012 $2^{[1]}$. This recent ARDL technique developed by Pesaran et al. (2001) has an advantage of capturing both long-run and short-run dynamics among variables. Compared to other conventional Cointegration techniques, this method can produce more robust and consistent estimates in small sample size studies.

The remaining of the paper is structured as follows. Section 2 reviews the theoretical background and empirical evidence. Section 3 describes data and research methodology. Section 4 reports key empirical results and major discussions. Section 5 gives concluding remarks and policy implications.

\section{THEORETICAL BACKGROUND AND EMPIRICAL EVIDENCE}

\section{a. Theoretical Background:}

A large volume of existing literature has been devoted to analyzing the existence of linkages between economic growth and FDI in both developed and developing countries. The hypothesis of FDI as an important determinant of economic growth seems to receive supportive evidence in theoretical strands. In fact, growth-enhancing effects of inward FDI have been viewed and explained differently by different economic growth theories. The neoclassical growth models and endogenous growth models can be considered as a theoretical foundation for FDI-led economic growth hypothesis of a country.

The neoclassical growth model was developed by Robert Solow and T.W. Swan in 1956. Accordingly, the key contribution of FDI to economic growth is stimulating capital accumulation in the host economy. FDI can channel required funds to the productive sectors of a capital-shortage economy. This process, in turn, helps increase output growth rate by increasing marginal productivity of capital. As shown in Figure 1, FDI inflows would foster capital stock available in the host economy (from $k_{0}$ to $k_{l}$ ), which then causes the investment function to grow from $\gamma \mathrm{y}\left(\mathrm{k}_{0}\right)$ to $\gamma \mathrm{y}\left(\mathrm{k}_{1}\right)$. Consequently, the recipient country will experience a higher level of output growth or higher level of steady state $\left(\mathrm{y}_{\mathrm{ss} 2}>\mathrm{y}_{\mathrm{ss} 1}\right)$. It is worth noting that in neoclassical growth models with diminishing returns to capital, FDI has only a "short-run" growth effect as countries move towards a 
new steady state. Therefore, the impact of FDI on growth is identical to that of domestic investment.

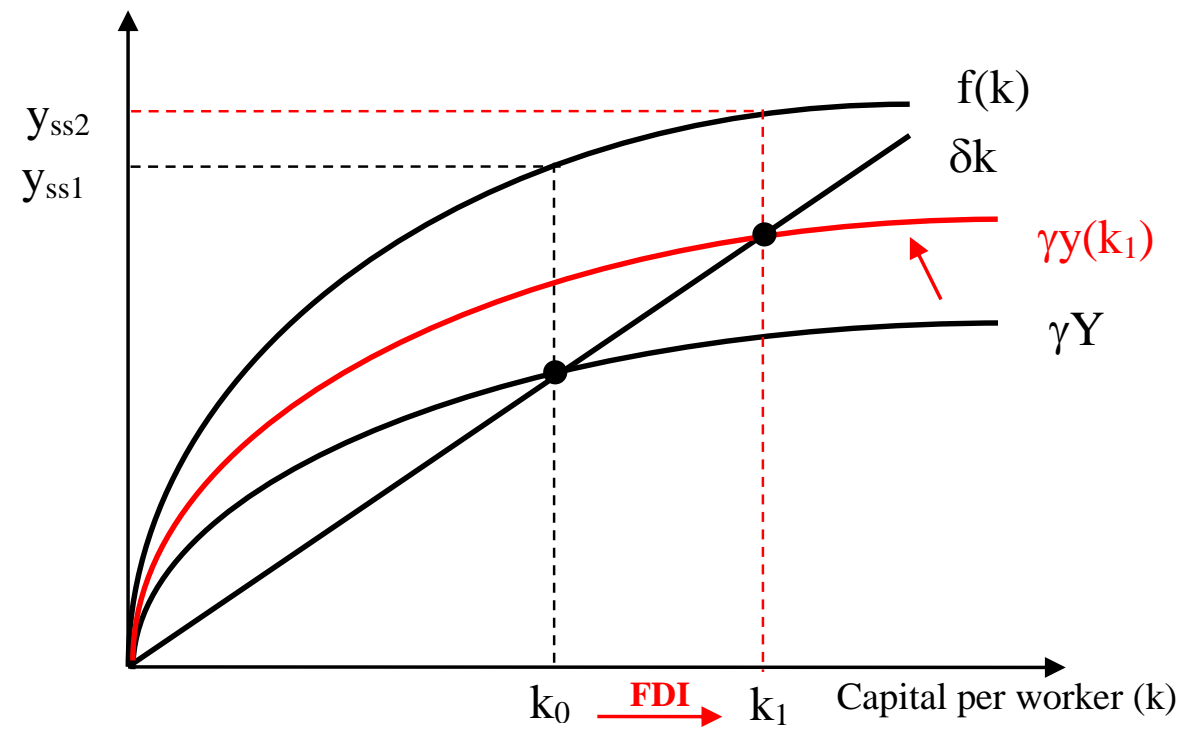

Figure 1: The Growth-Enhancing Effect of FDI in Neoclassical Growth Models

Meanwhile, in the endogenous growth models (Lucas, 1990; Romer, 1987; Mankiw, 1992), FDI is generally assumed to generate a more pronounced growth-enhancing impact and more productive than domestic investment. These new theorists argued that it was more than the direct capital inflows that FDI can help boost economic growth: FDI supplies direct capital with new technologies, managerial know-how, marketing, and R\&D capabilities. Consequently, the production function shifts up from $f(k)$ to $f^{\prime}(k)$, stimulating a higher level of productivity (output growth) from $y_{s s 1}$ to $y_{s s 2}$ as shown in Figure 2. In this view, FDI-related indirect effects (also known as spillovers or externalities) can offset the effects of diminishing returns to capital and keep the economy on a long-term growth path. 


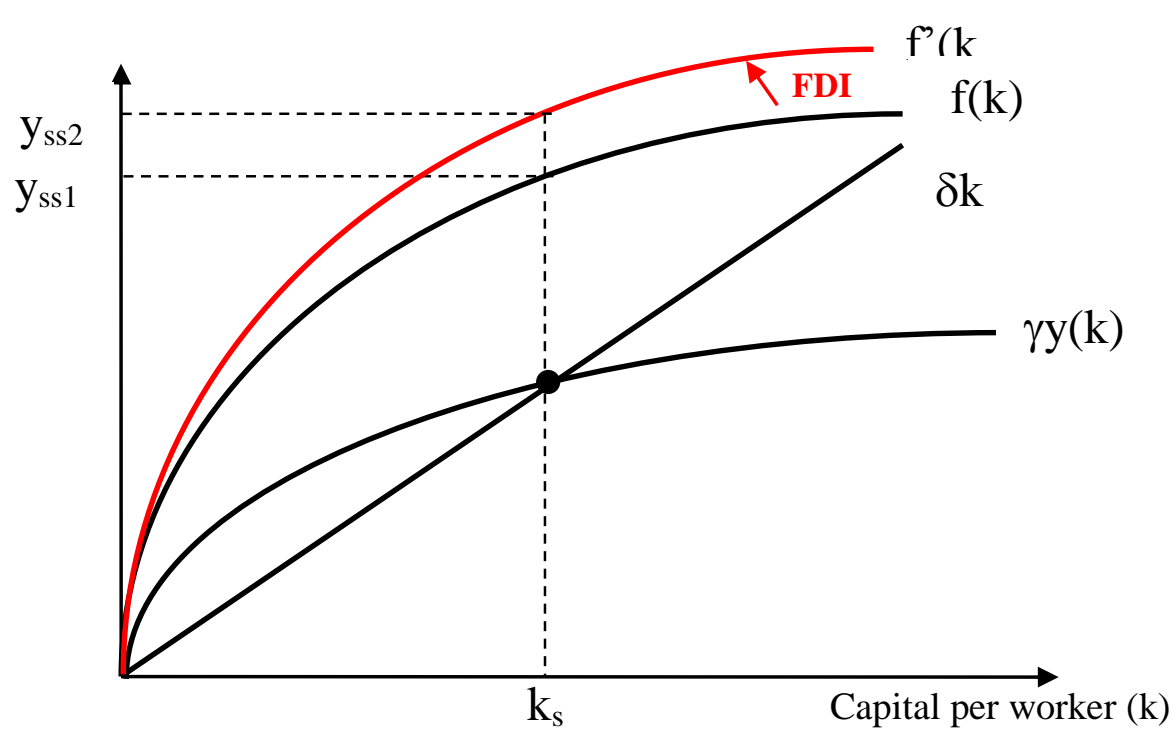

Figure 2: The Growth-Enhancing Effect of FDI in Endogenous Growth Models

\section{b. Empirical Evidence:}

While theoretical growth models gave a relatively unanimous support for FDI growth impact under different perspectives, empirical evidence is rather mixed. Bashir (1999) examined the FDI-growth link in six Middle East and North American countries over the years 1975-1990. By employing both random effect and fixed effect models, the author suggested that though the effect varied across regions and over time, FDI inflows by and large led to economic growth. Similarly, Liu et al. (2002) examined the FDIgrowth nexus in China over the period 1981-1997, employing the Granger causality test. Trade was included in the model to control for its impact on growth. Instead of using annual data as in the majority of existing papers, the authors applied quarterly data that can give more robust estimates. The findings indicated a two-way causality between FDI and growth. Meanwhile, Jayachandran \& Seilan (2010) adopted the same analysis approach of Granger causality test for India and only found a one-way causal effect from FDI to economic growth but not the other way round.

Compared to other conventional methods, the recent bounds testing technique has been widely applied in testing the FDI - growth relationship because of its robust and consistent estimates, particularly for small sample size studies of less than 30 observations. Apergis et al. (2008) employed a panel data set to examine FDI-growth nexus for 27 transition economies over the period 1991 - 2004. By using the ARDL 
Cointegration approach, the empirical evidence confirmed a significant relationship between the two variables for all countries. However, upon splitting the sample based on the level of income and privatization, the same conclusions hold only for the case of high-income economies and economies with successful privatization programs.

Applying the same ARDL technique, Ahmed et al. (2011) investigated the possible linkages between FDI, trade and economic development in Sub-Saharan African countries (Ghana, Kenya, Nigeria, South Africa and Zambia) during 1980 - 2004. The empirical findings supported the hypothesis of both short-run and long-run relationship between the variables. Notably, FDI was found to significantly stimulate economic growth in these countries, directly and indirectly through its effects on exports. Therefore, it was suggested that African countries should create a conductive environment and adopt more liberal policy framework to attract new FDI inflows.

In a similar attempt, Klasra (2009) employed the bounds testing technique to examine the FDI - growth linkage while accounting for trade openness in the case of Pakistan and Turkey during the period 1975 - 2004. The results indicated a long-run relationship between FDI and economic growth only for Pakistan. Meanwhile, FDI was found to induce export performance for Turkey in the short run. Shahbaz \& Rahman (2012) also applied the ARDL method to analyze the dynamics of financial development, imports, FDI and economic growth in Pakistan over the years 1990 - 2008. The findings confirmed the existence of a Cointegration relationship or long-run equilibrium between these series. In the short run, FDI was positively linked with economic growth although its impact was minor compared to other determinants ${ }^{[2]}$.

On the contrary, there are quite a few empirical studies arguing no independent and even negative growth effects of FDI on the host country. By resorting to Bayesian analysis, Katerina et al. (2004) investigated the existence and nature of FDI impact on the growth of 17 transition economies in Eastern Europe over 1995-1998. The results indicate insignificant relationship regardless of countries' development level. Similarly, Carkovic \& Levine (2006) examined this relationship for 72 countries during 19601995. FDI was found to create the crowding out effect on domestic capital and hence FDI did not have an independent and significant influence on economic growth.

Meanwhile, Udo \& Obiora (2006) examined this link for West African Monetary Zone over the years 1980-2002, using simultaneous equation method and Granger causality test. FDI was found to increase as a result of higher economic growth, but the 
other direction was not present. Athukorala (2003) analyzed the case of Sri Lanka, using vector autoregressive (VAR) method to investigate the causal relationship between FDI and GDP growth. The findings showed that FDI inflows did not exert an independent influence on economic growth and the causal direction was not from FDI to GDP growth but from GDP growth to FDI.

Lee (2009) employed the ARDL approach to empirically test the existence of a longrun relationship between FDI inflows, pollution and output of Malaysia. The data used was obtained from UNCTAD, covering the period of 1970 - 2000. The findings suggested that FDI explained only the short-run adjustment of GDP per capita. Nevertheless, the study failed to detect any long-run impact of FDI on output, which implied that FDI would not be an engine for sustained economic growth in Malaysia. According to the author, there might be three main reasons accounting for this unexpected outcome, including the instability and inconsistency of FDI inflows, the economic cycle of the investors' home countries and political considerations.

In the context of Vietnam, the majority of existing literature employs qualitative approach which examines key patterns, determinants and characteristics of FDI inflows. Meanwhile, the empirical quantitative studies remain limited, and particularly none of them applied the recent analysis technique of bounds testing to Cointegration. Nguyen (2006) employed a simultaneous equation model to investigate the FDI-growth linkage, using a panel dataset of 61 provinces over the years 1996-2003. The findings indicated a bi-directional causality between the examined variables. Similarly, Anwar \& Nguyen (2010) confirmed the significant growth impact of FDI on Vietnam's economy, suggesting that the impact would be greater if more resources were devoted to education and training, developing financial market and narrowing technology gap between foreign and local firms.

By using time-varying coefficients in an augmented production function and the feasible generalized least square estimation technique, Vu (2008) examined FDI growth impact in seven economic sectors of Vietnam. In this analysis, FDI was allowed to indirectly affect GDP growth via labor productivity. The results suggested that FDI inflows had a significant and positive effect on labor productivity and economic growth in Vietnam but the strong influence was not equally observed within the examined sectors. FDI was found to affect industrial sector, oil and gas, hotels and tourism, real 
estate business, and agriculture, meanwhile transportation and construction were the two sectors benefiting least from FDI.

Pham (2002) analyzed the pattern and determinants of FDI allocations and its growth impacts on various regions of Vietnam during 1988-1998. Regression analysis results showed that FDI inflows contributed to regional development by increasing capital stock and production output. FDI flows were, however, unevenly distributed among regions due to differences in infrastructure conditions, labor force quality and the scale of local market. Varamini \& Vu (2007) employed the ordinary least square (OLS) regression technique to look at the FDI-economic growth relationship in Vietnam during the period 1989-2005. The findings also suggested the significant impact of FDI inflows on Vietnam's economic growth.

\section{DATA AND RESEARCH METHODOLOGY}

The data used in this empirical analysis is the annual time series data obtained from the United Nations Conference on Trade and Development online statistics for the period 1991 - 2012 (UNCTAD, 2013). While some national databases are available, international databases such as UNCTAD, IMF, WB are more preferred in macroeconomic analysis, mostly because of their updatedness, popularity and credibility (Lee, 2009; Jayachandran \& Seilan, 2010; Ahmed et al., 2011; Apergis et al., 2008). The two variables: GDP is defined as GDP per capita and FDI is the value of annual foreign direct investment inflows to Vietnam ${ }^{[3]}$. Both variables are measured by US dollars at 2005 constant price and transformed to natural logarithm form (denoted by $l n$ ). Figure 3 gives an overview of GDP and FDI inflows to Vietnam during the studied period. The plotted data in logarithm form provides a closer and more comparative trending movement of the time series. It can be seen that both GDP and inward FDI series generally exhibit a similar upward trend over time. Nevertheless, FDI inflows show a more fluctuating pattern. The statistical software of STATA 11.0 is used for econometric analysis. 


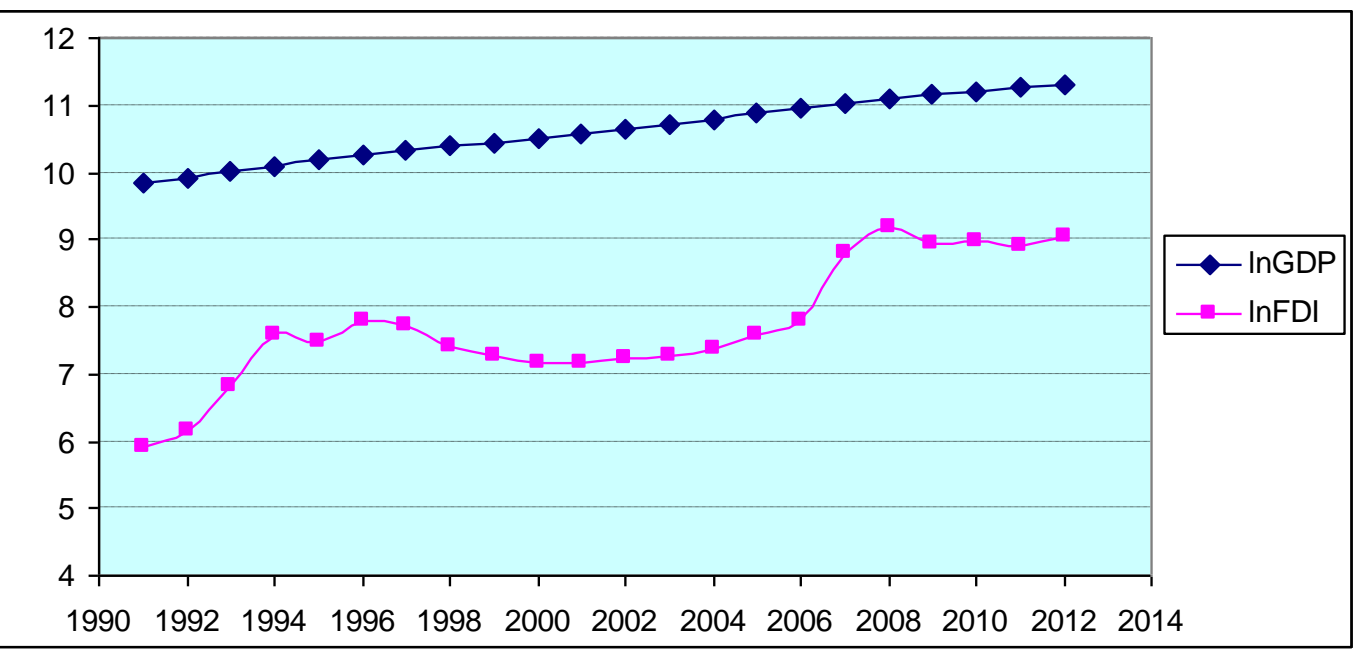

Figure 3: GDP and FDI inflows to Vietnam (1991 - 2012)

Prior to testing for Cointegration and causality, the first step is to examine the stationary properties of each individual time series under consideration ${ }^{[4]}$. A nonstationary time series will have a time-dependent mean and/or variance, which may result in spurious regressions under the classical regression situation. Therefore, the Dickey-Fuller (DF) test and the Augmented Dickey-Fuller (ADF) tests are performed to identify the order of integration of the two variables under investigation ${ }^{[5]}$. The advantage of ADF test over Dickey-Fuller unit root test is that it overcomes the autocorrelation problem that might exist in the time series. The ADF test can be used to test for unit root in the following three models:

$\begin{array}{ll}\text { (No intercept and p-lags) } & \Delta \mathrm{y}_{\mathrm{t}}=\gamma_{\mathrm{t}-1}+\sum_{\mathrm{i}=2}^{\mathrm{p}} \beta_{\mathrm{i}} \Delta \mathrm{y}_{\mathrm{t}-\mathrm{i}+1}+\varepsilon_{\mathrm{t}} \\ \text { (Intercept and p-lags) } & \Delta \mathrm{y}_{\mathrm{t}}=a_{0}+\gamma \mathrm{y}_{\mathrm{t}-1}+\sum_{\mathrm{i}=2}^{\mathrm{p}} \beta_{\mathrm{i}} \Delta \mathrm{y}_{\mathrm{t}-\mathrm{i}+1}+\varepsilon_{\mathrm{t}}\end{array}$

(Intercept, time-trend and p-lags) $\Delta \mathrm{y}_{\mathrm{t}}=a_{0}+\gamma \mathrm{y}_{\mathrm{t}-1}+a_{2} t+\sum_{\mathrm{i}=2}^{\mathrm{p}} \beta_{\mathrm{i}} \Delta \mathrm{y}_{\mathrm{t}-\mathrm{i}+1}+\varepsilon_{\mathrm{t}}$

The optimal lag length $p$ can be chosen by Akaike Information Criterion (AIC) and /or Schwarz Bayesian Criterion (SBC). In all three regressions, the objective is to test 
the following hypotheses: $H_{0}: \gamma=0$ (Non-stationarity) against $H_{1}: \gamma<0$

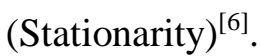

To test for the existence of a long-run relationship among variables, recent trend in Cointegration literature is to employ the bounds testing (or autoregressive distributed lagged - ARDL) approach developed by Pesaran et al. (2001) because of its advantages over other conventional Cointegration techniques such as Engle \& Granger (1987) and Johansen $(1988,1995)$. Notably, the bounds test approach is easy and simple to apply since the OLS method can be used to estimate the Cointegration relationship after determining the optimal lag order. More importantly, this recent procedure can fit small sample size studies like the present analysis. Finally, Pesaran et al. (2001) among others has showed that Cointegration can be tested within the ARDL framework without testing for unit root.

While the order of integration testing is not the prerequisite of bounds testing procedure, the unit root test is performed to check that none of the series exceed the integration of order one. This is because the critical values of the bounds test are developed for the variables that are I(0) and/or I(1) processes only. Accordingly, the ARDL model is employed to test for the existence of a long-run relationship between real GDP per capita ( $\ln G D P$ ) and $\ln F D I$ in Vietnam over the period 1988-2012. The ARDL models for the two variables take the following forms:

$$
\begin{aligned}
\Delta \ln G D P_{t}= & \alpha_{0}+\sum_{i=1}^{p_{1}} \alpha_{1 i} \Delta \ln G D P_{t-i}+\sum_{i=0}^{p_{2}} \alpha_{2 i} \Delta \ln F D I_{t-i}+\alpha_{3} \ln G D P_{t-1}+\alpha_{4} F D I_{t-1} \\
& +u_{1 t}
\end{aligned}
$$

Equations (4) and (5) are called the conditional ARDL-error correction models, where $\alpha_{3}, \alpha_{4}, \beta_{3}$ and $\beta_{4}$ are the long-run multipliers; $u_{1 t}$ and $u_{2 t}$ are white noise errors; $\Delta$ is the first difference operator; $p_{1}, p_{2}, q_{1}$ and $q_{2}$ are the lags included in the two different ARDL models. 
Both equations are then estimated by using the OLS technique. The null hypothesis of no long-run relationship is tested by employing Pesaran's F-type test for the joint significance of the coefficients of the lagged of RGDP and FDI variables in model (4) and (5), respectively:

$H_{0}: \alpha_{3}=\alpha_{4}=0$ (No Cointegration) against $H_{1}: \alpha_{3} \neq 0, \alpha_{4} \neq 0$ (Cointegration)

$H_{0}: \beta_{3}=\beta_{4}=0$ (No Cointegration) against $H_{1}: \beta_{3} \neq 0, \beta_{4} \neq 0$ (Cointegration)

Pesaran et al. (2001) has shown that the distribution of this F-statistic is non-standard irrespective of whether the explanatory variables are I $(0)$ or I(1), and has tabulated the appropriate critical values of the test. Accordingly, a pair of critical values (an upper and a lower bound) is provided given the number of repressors and the inclusion of an intercept and/or a time trend in the model. If the F-statistic is greater than the upper bound, the null hypothesis is rejected and supports the existence of a long-run relationship among the variables. If the F-statistic is smaller than the lower bound, the null cannot be rejected. Finally, if the statistic falls between the two bounds, then the result is inconclusive.

When the Cointegration hypothesis is confirmed for any model, the long-run relationship can be estimated by regressing $\ln G D P$ on $\ln F D I$ or vice versa. Accordingly, the error correction model (ECM) is established and estimated to examine the short-run dynamics among the two variables of interest.

$$
\begin{gathered}
\Delta \operatorname{lnGDP_{t}}=\alpha_{0}+\sum_{i=1}^{p_{1}} \alpha_{1 i} \Delta \ln G D P_{t-i}+\sum_{i=0}^{p_{2}} \alpha_{2 i} \Delta \ln G D P_{t-i}+\psi E C T_{t-1}+\eta_{1 t} \\
\Delta \ln F D I_{t}=\beta_{0}+\sum_{i=1}^{q_{1}} \beta_{1 i} \Delta \ln F D I_{t-i}+\sum_{i=0}^{q_{2}} \beta_{2 i} \Delta \ln G D P_{t-i}+\psi E C T_{t-1}+\eta_{2 t}
\end{gathered}
$$

Where $\alpha_{2 i}, \beta_{2 i}$ are the short-run dynamic coefficients, $\psi$ is the speed of adjustment and $E C T_{t-1}$ is one period lagged error correction term obtained from the estimated longrun model and defined in either equation (8) or (9) as follows:

$$
\begin{aligned}
& \ln G D P_{t}=\phi_{0}+\phi_{1} \operatorname{lnFDI_{t}}+E C T_{t}
\end{aligned}
$$

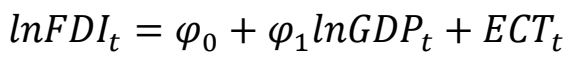

To investigate the causal relationship between $\ln G D P$ and $\ln F D I$, Granger causality test can be applied following the ECMs estimation. Theoretically, it is possible that (i) FDI-led growth hypothesis is true when the FDI improves the rate of growth of the host 
country; (ii) Growth-driven FDI hypothesis is true when the higher growth of the host economy attracts FDI; and (iii) the two-way effect indicates the bi-directional causality between them. Therefore, if the sequence $\left\{\ln G D P_{t}\right\}$ improves the forecast performance of $\left\{l n F D I_{t}\right\}$ then $\left\{l n G D_{P t}\right\}$ is said to Granger-cause $\left\{l n F D_{I t}\right\}$ and vice versa. However, in the ECM setup, the Granger causality test has to be conducted by testing the following joint hypothesis within the ECM equation (6) as follows:

$$
H_{0}: \alpha_{2 i}=\psi=0 \text { against } H_{1}: \alpha_{2 i} \neq 0, \psi \neq 0
$$

Similarly, whether $\left\{\ln G D_{P t}\right\}$ Granger-cause $\left\{\ln F D_{I t}\right\}$ can be tested by firstly estimating the ECM normalized on $\ln F D I$ as in equation (7). Then the null hypothesis of "no Granger-causality from GDP to FDI" $\left(H_{0}: \beta_{2 i}=\psi=0\right)$ is tested against the alternative $H_{l}: \beta_{2 i} \neq 0, \psi \neq 0$. These tests can be performed by using the restricted unrestricted version of F-test. If the null hypothesis is rejected in either case, then there is a unidirectional causality running between the two variables (either from GDP to FDI or vice-versa). If the null hypothesis is rejected for both equations, then there exists a bidirectional causality between GDP and FDI.

\section{EMPIRICAL RESULTS AND DISCUSSIONS}

\section{a. ADF Test for Unit Root:}

Before proceeding to the Cointegration and causality analysis, the time series data of $\ln G D P$ and $\ln F D I$ are tested to determine their order of integration. The result of the ADF unit root tests is reported in Table 1.

Table 1: ADF Unit Root Tests

\begin{tabular}{|c|c|c|c|c|c|}
\hline \multirow{2}{*}{ Variable } & \multirow{2}{*}{ Null hypothesis } & \multirow{2}{*}{$\begin{array}{c}\text { Test Statistics } \\
\text { (Lag) }\end{array}$} & \multicolumn{3}{|c|}{ Critical values } \\
\hline & & & $1 \%$ & $5 \%$ & $10 \%$ \\
\hline \multirow[t]{3}{*}{$\ln$ GDP } & $\gamma=0$ (No constant $)$ & $\tau=1.179$ & -2.66 & -1.95 & -1.60 \\
\hline & $\alpha_{0}=0, \gamma=0$ (Constant, no trend $)$ & $\tau_{\mu}=-1.183$ & -2.53 & -1.73 & -1.33 \\
\hline & (iii) $\alpha_{0}=0, \alpha_{2}=0, \gamma=0$ (Constant, trend) & $\tau_{\tau}=-2.930$ & -4.38 & -3.60 & -3.24 \\
\hline \multirow[t]{3}{*}{$\ln \mathrm{FDI}$} & $\gamma=0($ No constant $)$ & $\tau=0.713$ & -2.66 & -1.95 & -1.60 \\
\hline & $\alpha_{0}=0, \gamma=0$ (Constant, no trend $)$ & $\tau_{\mu}=-0.339$ & -2.53 & -1.73 & -1.33 \\
\hline & $\alpha_{0}=0, \alpha_{2}=0, \gamma=0($ Constant, trend $)$ & $\tau_{\tau}=-2.549$ & -4.38 & -3.60 & -3.24 \\
\hline
\end{tabular}




\begin{tabular}{llllll}
\hline \multirow{2}{*}{$\ln$ GDP } & $\gamma=0$ (No constant) & $\tau=-1.147$ & -2.66 & -1.95 & -1.60 \\
& $\alpha_{0}=0, \gamma=0$ (Constant, no trend) & $\tau_{\mu}=-2.168^{* *}$ & -2.53 & -1.73 & -1.33 \\
& $\alpha_{0}=0, \alpha_{2}=0, \gamma=0$ (Constant, trend) & $\tau_{\tau}=-2.413$ & -4.38 & -3.60 & -3.24 \\
\hline \multirow{2}{*}{$\Delta$ ln FDI } & $\gamma=0$ (No constant) & $\tau=-1.996^{* *}$ & -2.66 & -1.95 & -1.60 \\
& $\alpha_{0}=0, \gamma=0$ (Constant, no trend) & $\tau_{\mu}=-2.367^{* *}$ & -2.53 & -1.73 & -1.33 \\
& $\alpha_{0}=0, \alpha_{2}=0, \gamma=0$ (Constant, trend) & $\tau_{\tau}=-2.420$ & -4.38 & -3.60 & -3.24 \\
\hline
\end{tabular}

Note: $* * *, * *, *$ denotes significance at $1 \%, 5 \%$ and $10 \%$, respectively.

Since all test statistics in model (iii) for both $\ln G D P$ and $\ln F D I$ are greater than the critical values at $1 \%, 5 \%$, and $10 \%$ percent levels, the null hypothesis cannot be rejected. This indicates that both time series are non-stationary at level. Therefore, the first difference of the data is taken and tested for unit roots. The test statistics show that both differenced variables are stationary at 5\% level of significance. Therefore, $\ln G D P$ and $\ln F D I$ are integrated at the same order, or $\ln G D P \sim I(1)$ and In FDI I(1). In this case, there is a possibility of long-run relationship between these two variables. The ARDL approach now can be applied to check for Cointegration.

\section{b. ARDL Test for Cointegration:}

Since both $\ln G D P$ and $\ln F D I$ is I(1), it is possible that the two variables might be cointegrated. The Cointegration hypothesis is tested within the bounds testing procedure. Accordingly, the ARDL models for $\ln G D P$ and $\ln F D I$ take the following forms:

$$
\begin{aligned}
\Delta \ln G D P_{t}= & \alpha_{0} \\
+ & \sum_{i=1}^{2} \alpha_{1 i} \Delta \ln G D P_{t-i}+\sum_{i=0}^{2} \alpha_{2 i} \Delta \ln F D I_{t-i}+\alpha_{3} \ln G D P_{t-1}+\alpha_{4} F D I_{t-1} \\
& +u_{1 t} \\
\Delta \ln F D I_{t}=\beta_{0} & +\sum_{i=1}^{2} \beta_{1 i} \Delta \ln F D I_{t-i}+\sum_{i=0}^{2} \beta_{2 i} \Delta \ln G D P_{t-i}+\beta_{3} \ln F D I_{t-1}+\beta_{4} \ln G D P_{t-1} \\
& +u_{2 t}
\end{aligned}
$$

To examine the existence of a long-run relationship, the following hypotheses are tested for models (9) and (10) respectively: 


$$
H_{0}: \alpha_{3}=\alpha_{4}=0 \text { (No Cointegration) } \quad \text { against } \quad H_{1}: \alpha_{3} \neq 0, \alpha_{4} \neq 0
$$

(Cointegration)

$$
H_{0}: \beta_{3}=\beta_{4}=0 \text { (No Cointegration) } \quad \text { against } \quad H_{1}: \beta_{3} \neq 0, \beta_{4} \neq 0
$$

(Cointegration)

Table 2: ARDL Test for Cointegration

\begin{tabular}{lccc}
\hline F- Statistic & Significance level & \multicolumn{2}{c}{ Critical value } \\
\cline { 2 - 4 } & & Lower bound & Upper bound \\
\hline $\mathrm{F}_{\ln \mathrm{FDI}}(\ln \mathrm{GDP} / \mathrm{ln} \mathrm{FDI})=12.19 * * *$ & $1 \%$ & 5.754 & 6.483 \\
& $5 \%$ & 3.993 & 4.533 \\
$\mathrm{~F}_{\operatorname{lnGDP}}(\ln \mathrm{FDI} / \mathrm{ln} \mathrm{GDP})=5.87 * *$ & $10 \%$ & 3.247 & 3.773 \\
\hline
\end{tabular}

Note: $* * *, * *, *$ denotes significance at $1 \%, 5 \%$ and $10 \%$, respectively.

The calculated $F$-statistics is compared with the critical $F$ values in Narayan (2004) or Pesaran et al. (2001). Given the relatively small sample size in the present study, the critical values tabulated by Narayan (2004) are more relevant. The calculated $F_{\ln G D P}(\ln G D P \mid \ln F D I)=12.19$ and $F_{\ln F D I}(\ln F D I \mid \ln G D P)=5.87$ are greater than the upper bound critical value at 1-percent and 5-percent levels respectively, thus the null hypothesis of 'nonexistence of Cointegration' is rejected in both cases. This result suggests the existence of a long-run equilibrium linkage between the two variables when the regression is normalized on either $\ln G D P$ or $\ln F D I$. Alternatively, these two series will move (upward/downward) together in the long run.

Since the $F$-test result indicates that a Cointegration is present in the model (10), the ECM within the ARDL frame work takes the following form:

$$
\Delta l n F D I_{t}=\beta_{0}+\sum_{i=1}^{2} \beta_{1 i} \Delta \operatorname{lnFDI_{t-i}}+\sum_{i=0}^{2} \beta_{2 i} \Delta \ln G D P_{t-i}+\psi E C T_{t-1}+\eta_{2 t}
$$

where the error correction term $(E C T)$ is defined as: $E C T_{t-1}=\operatorname{lnFDI} I_{t-1}-\varphi_{0}-$ $\varphi_{1} \ln G D P$

The estimated ECM is reported in Table 3 as follows: 
Table 3: Estimates of the Error Correction Model

\begin{tabular}{lllll}
\hline \multicolumn{1}{c}{ Variable } & \multicolumn{1}{c}{ Coefficient } & Std. Error & T-Statistic & P_value \\
\hline Constant & $-2.673582 *$ & 0.8892966 & -3.01 & 0.011 \\
$\Delta \ln$ FDI (-1) & $0.931094 * * *$ & 0.201656 & 4.62 & 0.001 \\
$\Delta \ln$ FDI (-2) & $-0.3940888 * * *$ & 0.1233987 & -3.19 & 0.008 \\
$\Delta \ln$ GDP & $21.00209 * * *$ & 5.160428 & 4.07 & 0.002 \\
$\Delta \ln$ GDP (-1) & $-20.61249 * *$ & 7.882362 & -2.62 & 0.023 \\
$\Delta \ln$ GDP(-2) & $11.7887 *$ & 5.419962 & 2.18 & 0.050 \\
ECT(-1) & $-0.1702463 *$ & -0.0806622 & -2.11 & 0.056 \\
\hline
\end{tabular}

Note: $* * *, * *, *$ denotes significance at $1 \%, 5 \%$ and $10 \%$, respectively.

The coefficient on the error correction term $\left(E C T_{t-1}\right)$ represents the speed of adjustment back to the long-run relationship among the variables. It can be seen that the ECT term has a negative sign and is statistically significant at the 10-percent level, which also supports the result of the bounds test for Cointegration. The error correction coefficient indicates that $17.02 \%$ of the last year's disequilibrium is made up in the current year. This indicates a modest adjustment towards the long run equilibrium process.

\section{c. Granger Causality Test:}

To investigate the interrelationship between RGDP and FDI, the Granger causality tests are performed within the ECM for each of the variable under study as follows:

$$
\begin{aligned}
& \Delta \operatorname{lnGDP_{t}}=\alpha_{0}+\sum_{i=1}^{2} \alpha_{1 i} \Delta \operatorname{lnGDP_{t-i}}+\sum_{i=0}^{2} \alpha_{2 i} \Delta \ln G D P_{t-i}+\psi E C T_{t-1}+\eta_{1 t} \\
& \Delta \ln F D I_{t}=\beta_{0}+\sum_{i=1}^{2} \beta_{1 i} \Delta \ln F D I_{t-i}+\sum_{i=0}^{2} \beta_{2 i} \Delta \ln G D P_{t-i}+\psi E C T_{t-1}+\eta_{2 t}
\end{aligned}
$$

The Granger causality can be tested by restricting the coefficients of interest using the $F$-test. The null hypothesis and the test results are reported in Table 4. 
Table 4: Granger Causality Tests

\begin{tabular}{ccc}
\hline \multicolumn{1}{c}{ Null hypothesis } & F-Statistic & P-value \\
\hline $\mathrm{H}_{0}: \alpha_{2 \mathrm{i}}=\psi=0$ (ln FDI does not 'Granger cause' ln GDP) & $4.16^{* *}$ & 0.0242 \\
$\mathrm{H}_{0}: \beta_{2 \mathrm{i}}=\psi=0$ (ln GDP does not 'Granger cause' ln FDI) & $7.67^{* * *}$ & 0.0026 \\
\hline
\end{tabular}

Note: $* * *, * * *$ denotes significance at $1 \%, 5 \%$ and $10 \%$, respectively.

The $F$-statistic of 4.16 with the $P$-value of 0.0242 suggests the rejection of the null hypothesis of "No Granger causality from $\ln F D I$ to $\ln G D P$ ". In other words, FDI inflows stimulate GDP growth over the study period. At the same time, there is strong evidence that FDI is attracted by GDP growth since the null of "No Granger causality from ln GDP to $\ln F D I^{\prime}$ ' is rejected at 1-percent level of significance. Therefore, it can be concluded that there exists a bi-directional causality between $\ln G D P$ to $\ln F D I$ in Vietnam over the period 1991-2012. The finding of mutual reinforcing relationship between these two variables is expected and consistent with previous literature.

\section{CONCLUSION AND POLICY IMPLICATIONS}

This study examines the empirical econometric evidence of both causal and long run relationship between FDI inflows and economic growth in Vietnam over the period of 1991 - 2012. The recent and robust econometric approach of bounds testing (ARDL) to Cointegration is employed for its estimation advantages. The findings indicate the existence of a long-run equilibrium between FDI and growth in Vietnam during the study period. Having found a Cointegration evidence, the short-run dynamics associated with the long-run relationship were then examined in the ARDL model. The causal relationship between FDI and real GDP per capita within the ARDL is examined by applying Granger causality test which indicates a two-way causality between the two time series.

There are three important policy implications that could be drawn from the econometric results of this research. First, the empirical existence of a Cointegration relationship between inward FDI and economic growth in Vietnam implies that the values of these series are closely linked and their trending movements are similar in the long run. Thus, policy-makers could employ this finding for forecasting purpose in devising policies which may result in close impacts on these two essential variables.

Second, the results indicate that higher economic growth accompanied by increased per capita income has attracted increased inward FDI to Vietnam. In fact, output growth 
has been known as an indicator of growing market size, which signals huge potentials for foreign investors and builds up their confidence to invest in the host country (OECD, 1983; Moore, 1993; Meyer, 1998). This finding highlights the competitiveness of Vietnam as an FDI destination over the past few decades thanks to its high GDP growth rates. It is suggested that Vietnam should keep capturing this major advantage by consistently pursuing pro-growth policies in the future.

Third, FDI inflow is found to significantly contribute to economic growth, which is highly consistent with the existing literature for Vietnam (Nguyen 2006; Anwar \& Nguyen, 2010). For one thing, this empirical evidence validates the enormous efforts so far by the government in attracting FDI. For another, it supports further policies to lure this capital inflow, which could intensify its crucial role as Vietnam's main engine of sustained growth in the long term.

It should be noted that the use of time series data in this study might encounter a major concern of the instability of parameters through time. In fact, there is substantial empirical evidence of instabilities in the parameters of finance and macroeconomic models (Stock \& Watson, 1996; Ghysels, 1998; Primiceri, 2005). As suggested by Müller \& Petalas (2010), increasing sample size can help reduce the magnitude of the instability of the parameter path. Additionally, the current paper mainly deals with the FDI-growth nexus, thus it is of great interest to expand the empirical model to include other important variables (for example, domestic investment, trade, exchange rate, inflation rate, etc.). Such studies employing the ARDL framework could shed light on a more extensive dynamics of crucial macroeconomic time series and gain a more thorough perspective for policy recommendations. Finally, an increasingly popular strand of the FDI-growth studies in recent time is exploring spillover effects of FDI on recipient economies. Thus, further research is recommended to examine specific channels of spillovers, in which inward FDI can contribute to long-term growth of Vietnam so that the most efficient types of FDI are attracted and directed toward the most in-need areas of development in the economy

\section{Note}

[1] While the Foreign Investment Law was introduced in late 1987 and earliest projects were registered in 1988, the capital inflows were actually realized from the early 1990s onward. 
[2] Similar conclusions about positive FDI-growth impacts were supported by other empirical studies for both developed and developing economies such as Ireland (Kim \& Bang, 2008), Jordan (Alalaya, 2010), Mauritius (Ouattara, 2006) and Cyprus (Feridun, 2004).

[3] FDI inflow is a more widely used indicator (compared to FDI stock) in the growth-FDI studies (Apergis, 2008; Ahmed, 2011; Lee, 2009; Liu et al., 2002; Jayachandran \& Seilan, 2010; Katerina et al., 2004; Pham, 2002; Shahbaz \& Rahman, 2012).

[4] There is evidence in the literature that most of the macroeconomic variables are non-stationary (or integrated) at level (i.e., they tend to exhibit a deterministic and/or stochastic trend) (Hosseini et al., 2011).

[5] The DF and ADF unit root tests are universally used in the econometrics literature.

[6] The unit root test statistic is the same as the standard t-statistic but the critical values of the DF and ADF tests differ from the standard t-values. Dickey and Fuller (1976) have tabulated the critical values of the unit toot test corresponding to the various testing situations for different sample sizes.

\section{References}

Agosin, M.R. \& R. Mayer (2000), "Foreign Investment in Developing Countries: Does It Crowd in Domestic Investment", Discussion Paper 146, United Nations Conference on Trade and Development (UNCTAD), Geneva.

Ahmed, A. D., E. Cheng \& G. Messinis (2011), "The Role of Exports, FDI and Imports in Development: Evidence from Sub-Saharan African Countries", Applied Economics, 43(26), 37193731.

Alfaro L., A. Chanda, S. Kalemli \& S. Sayek (2004), "Foreign Direct Investment and Economic Growth: The Role of Local Financial Markets", Journal of International Economics, 64(1), 89112.

Anwar, S. \& L. P. Nguyen (2010), "Foreign Direct Investment and Economic Growth in Vietnam", Asia Pacific Business Review, 16, 183-202.

Apergis, N., K. Lyroudi \& A. Vamvakidis (2008), "The Relationship Between Foreign Direct Investment and Economic Growth: Evidence from Transition Countries", Transition Studies Review, 15(1), 37-51.

Athukorala, P.P.A. (2003), “The Impact of Foreign Direct Investment for Economic Growth: A Case Study in Sri Lanka", Paper presented at the 9th International Conference on Sri Lanka Studies, Matara.

Baliamoune-Lutz, M.N. (2004), "Does FDI Contribute to Economic Growth? Knowledge about the Effects of FDI Improves Negotiating Positions and Reduces Risk for Firms Investing in Developing Countries", Business Economics, 39(2), 49-56.

Bashir, A. M. (1999), "Foreign Direct Investment and Economic Growth in Some MENA Countries: Theory and Evidence", Paper presented at MENA Annual Meeting in Conjunction with the ASSA. 
Borensztein, E.J., J. D. Gregorio \& J. W. Lee (1998), "How Does Foreign Direct Investment Affect Growth?”, Journal of International Economics, 45(1), 115-135.

Carkovic, M. \& R. Levine (2005), “Does Foreign Direct Investment Accelerate Economic Growth?” in Moran, H.T., E. Graham \& M. Blomstrom (eds), Does Foreign Direct Investment Promote Development: New Methods, Outcomes and Policy Approaches, pp. 95-220. Institute for International Economics Press, Washington DC.

Engle, R.F. \& C.W.J. Granger (1987), "Cointegration and Error-Correction: Representation, Estimation, and Testing”, Econometrica, 55, 251-276.

Jayachandran, G. \& A. Seilan (2010), “A Causal Relationship between Trade, Foreign Direct Investment and Economic Growth for India", International Research Journal of Finance and Economics, 42, 74-88.

Ghysels, E. (1998), "On Stable Factor Structures in the Pricing of Risk: Do Time-Varying Betas Help or Hurt?”, Journal of Finance, 53, 549-573.

Johansen, S. (1988), "Statistical Analysis of Cointegration Vectors", Journal of Economic Dynamics and Control, 12, 231-254.

Katerina, L., P. John \& V. Athanasios (2004), "Foreign Direct Investment and Economic Growth in Transition Economies", South Eastern Europe Journal of Economics, 1, 97-110.

Klasra, M.A. (2011), "Foreign Direct Investment, Trade Openness and Economic Growth in Pakistan and Turkey: An Investigation Using Bounds Test”, Quality \& Quantity, 45(1), 223-231.

Lee, C. G. (2009), "Foreign Direct Investment, Pollution and Economic Growth: Evidence from Malaysia", Applied Economics, 41(13), 1709-1716.

Liu, X., P. Burridge \& P.J.N. Sinclair (2002), "Relationship Between Economic Growth, Foreign Direct Investment and Trade: Evidence from China", Applied Economics, 34, 1433-1440.

Meyer, K.E. (1998), Direct Investment in Economies in Transition, Cheltenham: Edward Elgar Publishers.

Moore, M.O. (1993), "Determinants of German Manufacturing Direct Investment: 1980-1998", Weltwirtschaftliches Archive, 129, 120 -137.

Müller, U.K. \& P.E. Petalas (2010), "Efficient Estimation of the Parameter Path in Unstable Time Series Models", The Review of Economic Studies, 77(4), 1508-1539.

Narayan, P.K (2004), "Fiji Tourism Demand: The ARDL Approach to Cointegration", Tourism Economics, 10(2), 193-206.

Nguyen Phi Lan (2006), "Foreign Direct Investment and Its Linkage to Economic Growth in Vietnam: A Provincial Level Analysis", Centre for Regulation and Market Analysis, University of South Australia.

OECD (1983), Investment Incentives, and Disincentives, and the International Investment Process, Paris: OECD Publications. 
Pesaran, M.H., Y. Shin \& R. J. Smith (2001), "Bounds Testing Approaches to the Analysis of Level Relationships”, Journal of Applied Econometrics, 16, 289-326.

Pham, H. M. (2002), “The Economic Impact of Foreign Direct Investment Flows in Vietnam: 198898”, Journal of The Asia Pacific Economy, 7(2), 182-202.

Primiceri, G. E. (2005), “Time Varying Structural Vector Auto regressions and Monetary Policy", The Review of Economic Studies, 72, 821-852.

Shahbaz, M. \& M.M. Rahman (2012), "The Dynamic of Financial Development, Imports, Foreign Direct Investment and Economic Growth: Cointegration and Causality Analysis in Pakistan", Global Business Review, 13(2), 201-219.

Stock, J. H. \& M. W. Watson (1996), "Evidence on Structural Instability in Macroeconomic Time Series Relations", Journal of Business and Economic Statistics, 14, 11-30.

Vu, Tam Bang (2008), "Foreign Direct Investment and Endogenous Growth in Vietnam", Applied Economics, 40, 1165-1173.

Udo, E.A. \& I. K. Obiora, (2006), "Determinants of Foreign Direct Investment and Economic Growth in the West African Monetary Zone: A System Equations Approach", Paper presented at the $9^{\text {th }}$ Annual Conference on Global Economic Analysis, Addis Ababa.

UNCTAD (United Nations Conference on Trade and Development) (2010), "World Investment Prospects Survey 2007-2009”, UNCTAD, Geneva [online; cited December 2010], available from http://unctad.org/en/docs/wips2007_en.pdf.

UNCTAD (2013), Online UnctadStat. UNCTAD, Geneva [online; cited June 2013], available from http://unctadstat.unctad.org/ReportFolders/reportFolders.aspx.

Varamini, H. \& A. Vu (2007), "Foreign Direct Investment in Vietnam and Its Impact on Economic Growth", International Journal of Business Research, 7, 132-139. 